\title{
Impact of Using Instructional Video Games on EFL Learners' Vocabulary Retention
}

\author{
Hadi Salehi \\ English Department, Faculty of Humanities, Najafabad Branch, Islamic Azad University, Najafabad, Isfahan, Iran
}

Copyright $(02016$ by authors, all rights reserved. Authors agree that this article remains permanently open access under the terms of the Creative Commons Attribution License 4.0 International License.

\begin{abstract}
This study aimed at investigating the impact of Instructional Video Games (IVGs) on the vocabulary retention of Iranian language learners. To do so, 32 male and 43 female, between the ages thirteen to thirty one years old, in Padideh Derakhshan Institute, Sahinshahr, Isfahan, Iran were selected as a whole population. First, the World English placement test was administered, and 60 learners were chosen as the participants of the study. Next, a test of novelty as a pretest of vocabulary was administered at the early stage of the study to ensure the novelty of to-be-instructed words and participants' unfamiliarity with those words. The experimental group members were treated with the new way of learning, IVGs, to practice the new words in each lesson, but control group members were treated with by memorizing the new words through a list. After four weeks both groups sat for vocabulary posttest, and about one month later they sat for delayed posttest. The results were compared statistically. The statistical analysis indicated significant difference in vocabulary retention on learners of the experimental group.
\end{abstract}

Keywords ICT, Instructional Video Games, Vocabulary, Iranian EFL Learners

\section{Introduction}

The crucial element in teaching and learning every language is vocabulary. In order to express one's idea, she/ he needs to learn satisfactory amounts of vocabularies. Vocabulary improvement can help learners to improve their language abilities. Words are arranged grammatically to form a message and one cannot learn a language without learning a great number of words [2]. Some scholars hold that learning vocabulary is more important than learning the grammar of a language [3].

Using multimedia in education is a revolution in learner's learning process. A number of research studies pointed out that suitably designed multimedia instruction increases students' learning performance in science, mathematics, and literacy [5]. Lately, computer-based video game's existence has been growing and game developers and researchers have started to examine video games' influence on students' intellectual learning [6]. Although some language teachers think that it's not a good idea to use language games in the classroom, especially for young kids, but it is important to study about its significance.

In recent years English has played a gradually important role as the medium of communication among people from different countries and Iran is not an exception. Nowadays English became a worldwide language, so learning this language through its vocabulary can help people to exchange their academic knowledge. Mastering vocabulary is one of the most challenging tasks that any learner faces while acquiring another language [7]. Thus, in the case of language learning, students need to be educated with the strategies which can help the learners acquiring the meaning of words. Blachowicz and Fisher [8] stated that providing a meaningful and rich environment for vocabulary learning, intentional instruction of chosen vocabularies, and providing multiple sources of information and repeated exposure are three essential principal features of effective vocabulary learning. To deal with vocabulary learning problems, vocabulary learning strategies should have been brought to the language classroom to enhance language learners' effectiveness in language learning.

Even though Iranian language learners experience learning English about seven years during their junior and senior high schools, however, many of them have difficulty in using it in a correct context, especially for speaking [10]. Language learners consider teachers' ways of teaching (explanation or definition of meaning, pronunciation, spelling, and grammatical functions) are boring. They also do not want to take risks in applying what they learnt. They may recognize a word in a written or spoken form and think that they already know the word, but they may not be able to use that word properly in different contexts or pronounce it correctly.

This study aims to answer the following research question: 
Is there any significant difference in vocabulary retention through using IVGs and through traditional method of vocabulary learning?

\section{Literature Review}

Hayes et al. [12] stated that vocabulary is something that cannot be completely mastered in a short duration of time but expands and deepens over the course of a lifetime. Tutoring in vocabulary involves far more than looking up words in a dictionary and using the words in a sentence. Vocabularies indicate complex and often several meanings and these complex and multiple meanings of words need to be understood in the context of other words in the sentences and paragraphs of texts. Not only students are expected to understand words in texts, but also texts can be expected to introduce them to many new words. The vocabulary of written language is much more widespread and diverse than the vocabulary of oral language [12].

Whether the language is first, second, or foreign vocabulary learning is fundamental to language acquisition. Interest in the role of vocabulary in second language (L2) learning has grown rapidly in recent years, although it has not always been known as a main concern in language teaching. Language specialists beside teachers and students are looking for a systematic and principled vocabulary teaching and learning approach. There is now universal agreement between vocabulary specialists that lexical competence is at the heart of communicative competence, the ability to communicate successfully and appropriately [13].

Vocabulary is acquired incidentally through indirect exposure to words and intentionally through explicit instruction in specific words and word-learning strategies. According to Hatch and Brown [14], vocabulary learning necessitates the following procedure: having sources for encountering new words, acquiring the word form, getting the word meaning, consolidating the word form and meaning, using the word.

Incidental vocabulary learning is learning that occurs when the mind is focused elsewhere, such as an understanding a text or using language for communicative purposes [15]. Ellis [16] claimed that implicit vocabulary teaching and learning method involves indirect, or incidental, whereas the explicit method involves direct or intentional. Flanigan and Greenwood [17] claimed that $90 \%$ of the words that a student learns over the course of a year are without direct instruction; these words are learned through incidental contact.

The game pattern is emphasized by the elements of organization which bring about a definite and often repeated climax; In a game, individuals do not lose their identity, for the game itself is a situation in which the elements of success and failure are so equally balanced that only players by their own efforts, practice, and application of self can swing the balance to succeed (pp.31-32).
IVGs are those fun activities that support interaction, thinking, learning, and problem solving strategies in the language classrooms. Often, games have a feature that permits the players (language learners) to construct information and/ or communication in a short time period. Some games require the players to engage in a physical activity and/or complete a mental challenge [19].

Using language games is going to become the best technique of teaching language skills. Using games in language learning involves factors such as rules, competition, comfort, and particularly learning. Helping learners to learn in a fun environment is the most important characteristic of using instructional games in an English language classroom [20]. It seems in a relaxed, motivating, and enjoyable environment, vocabulary acquisition occurs better where learners can concentrate on new words and their contextual usage. Several aids such as drawings, humorous behaviors, illustrations and games can be used in developing fun and enjoyable conditions [21]. Vocabulary games bring real world context into the classroom, and enhance students' use of English in a flexible, communicative way [22]. A really helpful way to get the shy students engaged in learning process is using games. Steinberg [23] claimed that playing games take the hard, boring work out of learning and provides motivation. Psychologically, games can remove those emotional filters from the learners' mind and offer them real-world motivation and instant need to apply linguistic items [24]. Moreover students become more active, autonomous and energetic, getting familiar with the environments and the world they live in [10].

\section{Methodology}

\subsection{Participants}

The participating subjects of main study were all the male and female pre-intermediate Iranian language learners at Padideh Derakhshan institute in Shahin Shahr, Isfahan, Iran. Thirty two male and forty three female learners of seven classes were whole the pre-intermediate EFL learners in that institute. At the beginning of the treatment World English Placement Test was administrated to ensure the homogeneity of the subjects, and then 15 participants were excluded from the study because their scores were either extremely higher or extremely lower than the mean score.. Three classes with 28 learners were chosen as the experimental group and four classes with 32 learners were chosen as the control group.

\subsection{Instruments}

\section{Test of Novelty}

A pretest of vocabulary consisted of a list of 32 new words which students had to write the meaning or explanation of those words. It was administered at the early stage of the study to ensure the novelty of the to-be-instructed words and 
participants' unfamiliarity with those words. The known words were excluded from the list of intended words and vocabulary items with which none of the students were familiar provided the material for the treatment.

\section{Game to Learn English}

The mini game for learning English made for the website gamestolearnenglish.com, the game was revised in January 2015 [25]. It has different parts for different purposes such as "big describer" for teaching and learning new words, "hang man" for spelling, "compare" for grammar and so on. Each part is an independent game and is available separately or as a compressed file on the internet and it may be downloaded.

There are four options in each part namely, designer, and review, slow and fast. When opening the review part, there are some categories such as food, sports, parts of the body, jobs, and so on. Selecting one category leads to opening a new window which teaches new words related to the selected category. There is a picture of the word with its name underlined and some definitions. At first learners can use slow button with the lower speed and when they became master enough they can use fast button with the higher speed. In the game window, there are several pictures and a definition of just one of them at the bottom, learners should read the definition and should select the correct picture. As fast as they can select the correct item their score would be higher. If they cannot find the correct answer, the redundant pictures disappear and just two pictures will be remained. Time and score will be calculated at the end and each learner score can be compared to each other in order to motivate and raising the sense of competition among them.

\section{Posttest}

This test includes twenty multiple-choice items based on the learned vocabularies on the test. Test validity was confirmed by some expert teachers. The reliability of the test was confirmed by the pilot study which was done in three other institutes by 45 pre-intermediate learners ( 25 female and 20 male learners). The result was analyzed and alpha Cronbach coefficient was above the 0.6

\section{Delayed Posttest}

One month after the administration of the posttest administrated, another test was conducted again as a delayed posttest to examine the retention on learned new words..

\section{Booklet}

A booklet which was a list of fifty new vocabularies under five categories with their definition was given to each participant. Control group just used this booklet to memorize the vocabularies but experimental group even received the booklet and the game $\mathrm{CD}$ to learn the vocabularies.

\subsection{Procedure}

First, the World English Placement Test was administered to select the homogenize sample, and sixty learners whose scores were between twenty \& twenty nine were selected. Twenty eight learners in three classes were chosen as experimental groups and thirty two learners in four classes were chosen as control groups.

At outset of the test of novelty was administered.

Experimental group members received the treatment which was teaching and learning vocabularies with IVGs. A game's CD and a booklet were given to each learner in experimental group and just a booklet to each participant in control group. At the first section teacher explained about how the learners can use the game. In one part of the game new words were presented with a picture of that item and four explanations of that word. To memorize the new words learners had to practice the game at home. Control group members received traditional way of learning the new words, which was the repeating and memorizing a list of new words. A booklet was given to each learner in control group. And they had to memorize the new vocabularies from the list.

And finally after eight sessions the vocabulary posttest was administrated to examine the retention the learnt vocabulary. There was a slightly difference between groups but that was not significant. Four weeks later delayed posttest was administrated. It was the same as posttest, just the order of the questions and the arrangement of the answers were changed in order to prevent guessing. The result showed the significant difference.

\section{Results and Discussion}

In order to answer the research question, first the placement test was run to insure the homogeneity of the groups' members' proficiency level. Table1 shows the placement test scores for both control and experimental groups. There was not noticeable difference between the groups mean and the most important was the significance which is 0.89 . It means that there was no significant difference between the groups and they were homogeneous.

Multiple vocabularies posttest was run for both control and experimental groups. Five categories of new words were taught. Four weeks after the posttest, the delayed posttest was run and the results of control and experiment group were compered to examine which group had a better retention.. The results of the independent sample t-test are presented below. 
Table 1. Groups' comparison of placement test scores

\begin{tabular}{ccccccccc}
\hline Test score & Sig. & $\mathrm{t}$ & $\mathrm{f}$ & $\begin{array}{c}\text { Sig. } \\
\text { (2-tailed) }\end{array}$ & \multicolumn{2}{c}{$\begin{array}{c}\text { Mean } \\
\text { Control }\end{array}$} & Test & \multicolumn{2}{c}{$\begin{array}{c}\text { Std. Deviation } \\
\text { Control }\end{array}$} & Test \\
\hline \multirow{2}{*}{ Placement Test Score } & .89 & -0.53 & 8.00 & 0.60 & 21.83 & 22.30 & 3.42 & .39 \\
\hline
\end{tabular}

Then after the fourth week, eight sessions, of the treatment,

Table 2. Comparison of the groups' posttest scores

\begin{tabular}{|c|c|c|c|c|c|c|c|c|c|c|}
\hline \multirow{2}{*}{$\begin{array}{l}\text { Test } \\
\text { Score }\end{array}$} & \multirow{2}{*}{ Sig. } & \multirow{2}{*}{$\mathrm{t}$} & \multirow{2}{*}{$\mathrm{df}$} & \multirow{2}{*}{$\begin{array}{l}\text { Sig.(2 } \\
\text { tailed) }\end{array}$} & \multirow{2}{*}{$\begin{array}{c}\text { Mean } \\
\text { Difference }\end{array}$} & \multirow{2}{*}{$\begin{array}{l}\text { Std. Error } \\
\text { Difference }\end{array}$} & \multicolumn{2}{|c|}{ Mean } & \multicolumn{2}{|c|}{ Std. Deviation } \\
\hline & & & & & & & Control & Experiment & Control & Experiment \\
\hline Post & 0.13 & -1.33 & 58.00 & 0.19 & -0.53 & 0.40 & & & & \\
\hline $\begin{array}{l}\text { Test } \\
\text { Score }\end{array}$ & & -1.33 & 56.34 & 0.19 & -0.53 & 0.40 & 16.17 & 16.70 & 1.42 & 1.68 \\
\hline
\end{tabular}

Table 3. The comparison of groups' delayed posttest scores

\begin{tabular}{|c|c|c|c|c|c|c|c|c|c|c|}
\hline \multirow{2}{*}{$\begin{array}{c}\text { Test } \\
\text { Score }\end{array}$} & \multirow{2}{*}{ Sig. } & \multirow{2}{*}{$\mathrm{t}$} & \multirow{2}{*}{ df } & \multirow{2}{*}{$\begin{array}{l}\text { Sig.(2- } \\
\text { tailed) }\end{array}$} & \multirow{2}{*}{$\begin{array}{c}\text { Mean } \\
\text { Difference }\end{array}$} & \multirow{2}{*}{$\begin{array}{l}\text { Std. Error } \\
\text { Difference }\end{array}$} & \multicolumn{2}{|c|}{ Mean } & \multicolumn{2}{|c|}{ Std. Deviation } \\
\hline & & & & & & & Control & Experiment & Control & Experiment \\
\hline $\begin{array}{l}\text { Delayed } \\
\text { Post }\end{array}$ & 0.03 & -2.44 & 58.00 & 0.02 & -1.17 & 0.48 & & & & \\
\hline $\begin{array}{l}\text { Test } \\
\text { Score }\end{array}$ & & -2.44 & 55.68 & 0.02 & -1.17 & 0.48 & 15.37 & 16.53 & 1.65 & 2.03 \\
\hline
\end{tabular}

As it was shown in Table 2, there is no significant difference between groups' results. It means that using IVGs does not have any noticeable effect on vocabulary learning and teaching. But to check the difference between vocabularies' retention a delayed posttest was run. The result was shown in the following table.

The results of Table 3 showed that there was a significant difference between the participants' scores on delayed posttest $(\mathrm{P}<0.05)$. It means that the experimental group members which use IVGs had better retention in learning vocabularies indicating that using IVGs had a positive significant effect on vocabulary retention. It means that using IVGs have positive significant effect on Iranian pre-intermediate EFL learners' vocabularies retention.

\section{Conclusions}

Long term retention of the taught new words is the goal of language teachers and language learners. IVGs have an important role in increasing success of the language learners in vocabulary learning. Teachers can apply different activities to help their students to have better retention. Using IVGs is a good and innovative way to encourage students and arouse their motivation which leads to increase learning. As a reinforcing device for teaching vocabularies in order to transfer learned items from short to long term memory using IVGs plays an important role [26]. The results of this study showed that there is a significant difference in remembering the learned vocabularies between groups by using IVGs. Through using IVGs, participants had better retention according to analysis of the statistical results of the delayed posttest.

\section{REFERENCES}

[1] Přibilová L. Teaching vocabulary to young learners. MASARYK UNIVERSITY; 2006.

[2] Kang S-H. The effects of a context-embedded approach to second-language vocabulary learning. System. Elsevier; 1995;23(1):43-55.

[3] Aslanabadi H, Rasouli G. The effect of games on improvement of Iranian EFL vocabulary knowledge in kindergartens. Int Rev Soc Sci Humanit. 2013;6(1):186-95.

[4] Chen Y-T, Huang H-W, Liu C-H. Using Instructional Software to Improve Oral Performance of Taiwanese Speakers of English in Higher Education. Int J English Lang Teach. 2013;1(1):p42.

[5] Gee JP. What video games have to teach us about learning and literacy. Comput Entertain. ACM; 2003;1(1):20.

[6] Begg M, Dewhurst D, Macleaod H. Game-informed learning: Applying computer game processes to higher education. Innov J Online Educ. 2005;1(6):6.

[7] Nyikos M, Fan M. A review of vocabulary learning strategies: Focus on language proficiency and learner voice. Lang Learn Strateg. Oxford University Press Oxford; 2007;30:251-74.

[8] Blachowicz CLZ, Fisher P. Teaching vocabulary in all classrooms. Merrill/Prentice Hall; 2002.

[9] Dóczi B. Comparing the vocabulary learning strategies of high 
school and university students: A pilot study. WoPaLP. 2011;5:138-58.

[10] Eskandari Z, Khonmohammad H, Komeijanifarahani AA. THE EFFECT OF USING GAMES ON ENGLISH GRAMMAR. 2014;5(January):458-71.

[11] Stahl SA. Four problems with teaching word meanings. Teach Learn Vocab Bringing Res to Pract. Routledge; 2005;95-114.

[12] Hayes DP, Wolfer LT, Wolfe MF. Schoolbook simplification and its relation to the decline in SAT-verbal scores. Am Educ Res J. Sage Publications; 1996;33(2):489-508.

[13] Coady J, Huckin T. Second language vocabulary acquisition: A rationale for pedagogy. Cambridge University Press; 1997.

[14] Hatch E, Brown C. Vocabulary, Semantics, and Language Education. ERIC; 1995.

[15] Celce-Murcia M. Teaching English as a Second Or Foreign Language [Internet]. Heinle \& Heinle; 2001. Available from: https://books.google.com/books?id=7cW5QgAACAAJ

[16] Ellis NC. Implicit and explicit learning of languages. Academic Press; 1994.

[17] Flanigan K, Greenwood SC. Effective Content Vocabulary Instruction in the Middle: Matching Students, Purposes, Words, and Strategies. J Adolesc Adult Lit [Internet]. 2007 Nov 9 [cited 2015 Dec 25];51(3):226-38. Available from: http://doi.wiley.com/10.1598/JAAL.51.3.3

[18] Hunt SE, Cain E. Games the World Around. Ronald Press
Company; 1941.

[19] Talak-Kiryk A. Using Games In A Foreign Language Classroom. 2010;

[20] Valipour V, Assadi Aidinlou N. THE EFFECT OF LANGUAGE GAMES ON LEARNING ENGLISH LISTENING-SPEAKING SKILLS OF IRANIAN PRE-SCHOOL. Indian $\mathrm{J}$ Fundam Appl Life Sci. 2014;4(2):647-50.

[21] Ashraf H, Motlagh FG, Salami M. The Impact of Online Games on Learning English Vocabulary by Iranian (Low-intermediate) EFL Learners. Procedia-Social Behav Sci. Elsevier; 2014;98:286-91.

[22] Huyen NTT, Nga KTT. Learning Vocabulary through Games: The Effectiveness of Learning Vocabulary through Games. The Asian EFL Journal. 2013.

[23] Steinberg J. Games language people play. Pippin Pub Ltd; 1983.

[24] Vossoughi H, Clair E. Language Games and Just-a-Minute. Tehran: Rahnama Publisher; 1994.

[25] Dwyer O. No Title [Internet]. 2013. Available from: http://www.answers.com/Q/What_is_the_definition_of_ICT _tools

[26] Jafari D, Madani D, Maghsoudi M. The Effect of Using the Instructional games on Iranian EFL Learners' Vocabulary Achievement and Their Retention. Lang India. 2013;13(10). 